\title{
Norman W. Johnson (12 November 1930 to 13 July 2017)
}

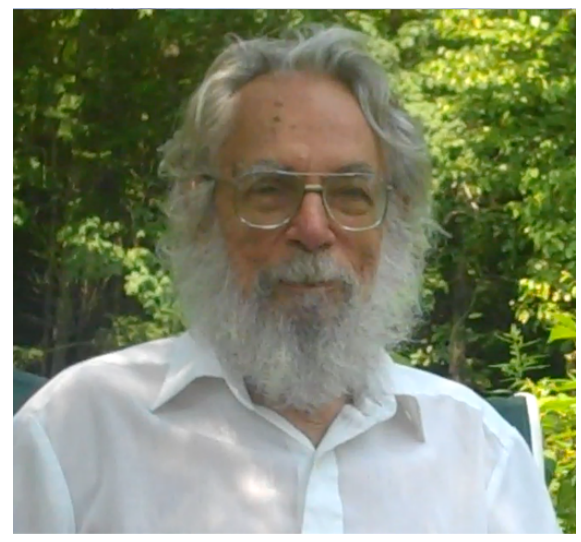

Norman W. Johnson was born on November 12, 1930 in Chicago, where his father had a bookstore and ran a local newspaper. He attended Carleton College, graduating in 1953 . He did alternative service as a conscientious objector then went on to earn a Master's degree from the University of Pittsburgh. He then went to the University of Toronto to work with H. S. M. Coxeter in geometry. After receiving his $\mathrm{PhD}$ in 1966 he accepted a position in the Mathematics Department of Wheaton College in Massachusetts and taught there until his retirement in 1998. He is known for the "Johnson Solids," the ninety-two non-uniform convex solids with regular faces that he identified in a 1966 article [1] and speculated was the complete set. He also published a number of other articles on various aspects of polytopes. He died on July 13, 2017, but his completed book, Geometries and Transformations [2], is forthcoming from Cambridge University Press. His nearly-completed work on uniform polytopes, the subject of his dissertation, will be appearing.

Asia Ivić Weiss and Eva Marie Stehle

\section{References}

[1] N. W. Johnson, Convex polyhedra with regular faces, Canad. J. Math. 18 (1966), 169-200, doi: 10.4153/cjm-1966-021-8.

[2] N. W. Johnson, Geometries and Transformations, Cambridge University Press, Cambridge, 2017. 